2015-03

\title{
Determinants of crop diversity in the regions of Bangladesh (1990-2008)
}

\author{
Rahman, Sanzidur
}

http://hdl.handle.net/10026.1/3774

10.1111/sjtg.12086

Singapore Journal of Tropical Geography

Wiley

All content in PEARL is protected by copyright law. Author manuscripts are made available in accordance with publisher policies. Please cite only the published version using the details provided on the item record or document. In the absence of an open licence (e.g. Creative Commons), permissions for further reuse of content should be sought from the publisher or author. 
SJTG-13-075.R1

(Revised version incorporating all comments of the referee)

Singapore Journal of Tropical Geography 36 (2015) 83-97

(C) 2014 Department of Geography, National University of Singapore and Wiley

Publishing Asia Pty Ltd

\title{
Determinants of crop diversity in the regions of Bangladesh (1990-2008)
}

\author{
Sanzidur Rahman1 and Mohammad Mizanul Haque Kazal2 \\ 1School of Geography, Earth and Environmental Sciences, Plymouth University, Devon, UK \\ 2Department of Poverty Studies, Sher-e-Bangla Agricultural University, Dhaka, Bangladesh \\ Correspondence: Sanzidur Rahman (email: srahman@plymouth.ac.uk)
}

\section{Acknowledgement:}

The database required for this project is created with funding support from Seale-Hayne Education Trust, UK (2011), British Academy Small Research Grant (2009) and National Food Policy Capacity Strengthening Program, FAO-Bangladesh Research Grant, Phase II (2011). An earlier version of this paper appears as a chapter in the report "Financial and economic profitability of selected agricultural crops in Bangladesh" NFPCSP-FAO Research Grant Report \#05/11, Dhaka Bangladesh, July 2013. 


\title{
Determinants of Crop Diversity in the Regions of Bangladesh (1990-2008)
}

\begin{abstract}
The paper measures the level of crop diversity and identifies factors influencing diversification using a panel data of 17 regions of Bangladesh covering a 19 year period (1990-2008). Results revealed that the trends in area allocated to HYV rice, spices and vegetables has increased while area under traditional rice, minor cereals, oilseeds, pulses, jute and sugarcane has declined at variable rates across regions with significant differences. The level of crop diversity is also significantly different across regions and has decreased in 2008 from its 1990 level in most regions except Faridpur, Khulna and Sylhet. Among the determinants, an increase in the relative prices of vegetables and urea fertilizer, extension expenditure, labour stock per farm, average farm size, irrigation and a reduction in livestock per farm significantly increase crop diversity. Price policies to improve vegetable prices and investment in irrigation infrastructure and extension services are suggested to promote crop diversity in Bangladesh.
\end{abstract}

Key Words: Crop diversity, socio-economic and environmental factors, random effects regression, Bangladesh.

\section{Introduction}

Agricultural diversification is considered as an important strategy to overcome the challenges faced by many developing countries due to the opportunities it offers for risk management, tackling heterogeneous production conditions, and increased income generation through entry into new markets (Winters et a., 2006). Diversification of agriculture means developing a larger number crop- or enterprise-mix in favour of high-value and more remunerative enterprises (Ali, 2004). It refers to a shift from the regional dominance of one crop to regional production of a number of crops, e.g., cereals, pulses, vegetables, fruits, oilseeds, fibres, fodder and grasses, fuel, 
etc. in order to meet their increasing demand (Singh, 2011). Promotion of crop diversification also has important implications for biodiversity (Winters et al., 2006). Agricultural diversification is also a tool for development in addition to a function of enhanced income, sustainability and risk reduction (Ali et al., 2004). South Asia is diversifying its agriculture in order to meet the challenge of global competitive market, change in demand and tastes of the population as well as to augment farm income, generate employment, alleviate poverty and conserve precious soil and water resources (Bhattacharyya, 2008). In fact, rising prices and crop diversification has been identified as the major sources of growth in Indian agriculture during the 1980s (Joshi et al., 2006).

Bangladesh, dominated by rice culture accounting for $79.2 \%$ of the gross cropped area (GCA) (BBS, 2011), is seeking to diversify its agricultural sector to other cereals (i.e., wheat and maize) as well as non-cereals (e.g., potatoes, vegetables, and spices, etc.). In fact, the Fifth Five Year Plan (FFYP: 1997-2002) set specific objectives to attain self-sufficiency in foodgrain production along with increased production of other nutritional crops, as well as to encourage export of vegetables and fruits, keeping in view domestic consumption demand and nutritional requirements $(\mathrm{PC}, 1998)$. The FFYP also earmarked $8.9 \%$ of the total agricultural allocation to promote crop diversification. Subsequently, the Poverty Reduction Strategy Paper (2005) and the Sixth Five Year Plan (SFYP: 2011-2015) also emphasized crop diversification (PC, 2011, IMF, 2005) although no specific budget was earmarked in these plan documents.

Farmers in Bangladesh grow multiple crops with rice in order to meet subsistence as well as cash requirement (Rahman, 2009). However, expansion of non-cereals (e.g., potatoes, vegetables, onions and cotton), which are profitable than rice cultivation, are slow because of the incompatibility of the existing irrigation system that is mainly suitable for rice production only 
(Mahmud, Rahman and Zohir, 1994). The countrywide diffusion of a rice-based 'Green Revolution' (GR) technology since the beginning of the 1960s to fulfil the goal of foodgrain selfsufficiency has largely been paid off in recent years (Rahman, 2010). However, there is a concern that the achievement in foodgrain self-sufficiency may have come at a cost of losing crop diversity of the nation which potentially threatens sustainability of the agricultural system. For example, Husain, Hossain and Janaiah (2001) noted that the intensive monoculture of rice led to a displacement of land under low productive non-rice crops such as pulses, oilseeds, spices and vegetables, leading to an erosion of crop diversity, thereby, endangering the sustainability of crop-based agricultural production system. Contradictory to such assertion, Rahman (2009), by comparing aggregate national data between two agricultural censuses of 1960 and 1996, noted that crop diversity has actually increased by $4.5 \%$ and the share of non-cereal crops in GCA has declined by only $2 \%$ over this 36 year period. Furthermore, Rahman (2010) concluded that the Shannon index of crop diversity actually grew at an annual rate of $0.6 \%$ over the 59 year period (1948-2006).

Recently, the National Food Policy Capacity Strengthening Program (NFPCSP) of the FAO and the Ministry of Food and Disaster Management, Bangladesh conducted a large scale survey from 17 districts of Bangladesh to examine profitability of cereal and non-cereal crops (specifically, high yielding varieties of rice, aromatic rice, wheat, maize, lentil, mustard, and jute) (Kazal et al., 2013). The results indicated that although all crops under investigation are profitable with Benefit Cost Ratio ranging from 1.2-1.5, the highest net return per ha is obtained from aromatic rice followed by high yielding Boro rice (dry winter season). Only jute grown in the south-central region closely follows net return levels of Boro rice while all other crops yield far lower returns (Kazal et al., 2013). This perhaps explains a declining trend in the share of non- 
cereal crops in GCA in Bangladesh during the 1948-2006 at the rate of 0.2\% per year (Rahman, 2010). It is worth noting that the conclusions made by Rahman (2010) are based on national level data which masks variation in individual regions. Bangladesh has some areas/districts where non-cereal and/or non-rice crops also dominate along with rice (e.g., Chittagong Hill Tracts, Faridpur, Kushtia, and Jessore). The reasons for higher level of crop diversity in these regions include undulated and highlands (mainly in Chittagong Hill Tracts) and lack of widespread irrigation.

Few studies exist on the analysis of agricultural diversity in South Asian region (e.g., Ali, 2004; Ali et al., 2004; Singh et al., 2006). For example, Ali (2004) provided an overview of the agricultural diversification and international competitiveness based on detailed analysis and selected country reports from Asia and highlighted the need for improvement in infrastructure, technological progress and market reform among others. Ali et al., (2004) noted that diversification of food into vegetables improve earning capacity of manual labourers in Pakistan Punjab due to balanced diet, reduced illness and higher productivity. Singh et al., (2006) examining diversification of Indian agriculture using state level data for two years (i.e., 1991 and 2001) noted that diversification into non-food grains increased mainly to mitigate risk rather than enhance income and electricity and road density are negatively associated with diversification.

Given the emphasis of the Bangladeshi government to diversify its agricultural sector (e.g., Kazal et al., 2013; PC 2011; IMF 2005), it is important to know how the regions has responded to these policy drives and identify the factors determining crop diversity at the regional level over time, so that well informed policy instruments can be developed and implemented. In order to fulfil this gap in information, the present study uses a wide range of price and non-price factors to identify determinants of crop diversification at the regional level in Bangladesh covering a 
period of two decades (i.e., 1990-2008). We do so by estimating a model of crop choice based on a theoretical framework of the farm household model applying a micro-econometric approach.

The rest of the paper is structured as follows. Section 2 presents the analytical framework of the study, develops the empirical model, and describes the data. Section 3 presents the results. Section 4 provides conclusion and draws policy implications.

\section{Methodology}

\subsection{The Theoretical Model}

First, we develop a general model of farm production to examine the determinants of crop diversity and or area allocated to different crops following Rahman (2008). The farmer produces a vector $Q$ of farm outputs using a vector of inputs $X$. The decision of choice, however, is constrained by a given production technology that allows combination of inputs $(X)$ and an allocation of a fixed land area $\left(A=A^{0}\right)$ among $j$ number of crops, given the characteristics of the farm (Z). The total output of each farmer $i$ is given by a stochastic quasi-concave production function:

$$
Q_{i j}=f\left(X_{i j k} \ldots X_{i j k}, \varepsilon \mid A_{i}, Z_{i}\right)
$$

where $\varepsilon$ is the stochastic variable indicating impacts of random noise. It is assumed that $f_{X k}>0$ and $f_{X X k}<0$. Each set of area shares $\left(\alpha_{j}\right)$ among $j$ crops sums to $1, \sum_{j}^{J} \alpha_{j}=1, j=1,2, \ldots . J$, which maps into the vector $Q$ through physical input-output relationships. The choice of area shares implies the level of farm outputs. The profit of each farm $i$ is given by:

$$
\pi_{i}\left(Q, X, p, w \mid A_{i}, Z_{i}\right)=\sum_{j=1}^{J} p_{j} Q_{i j}-\sum_{k=1}^{K} w_{j} X_{i j k}
$$

where $p$ is the vector of output prices and $w$ is the vector of input prices. 
The farmer is assumed to have a von Neuman-Morgenstern utility function, $U(W)$ defined on wealth $W$ with $U_{W}>0$ and $U_{W W}<0$. The wealth is represented by the sum of initial wealth $\left(W_{0}\right)$ and the profit generated from farming $(\pi)$. Therefore, the objective of each farm is to maximize expected utility as (Isik, 2004):

$$
E U\left(W_{0}+\pi\left(Q, X, p, w \mid A_{i}, Z_{i}\right)\right.
$$

where $E$ is the expectation operator defined over $\varepsilon$. The choice variables in (3), the farm's input levels $X_{i j k}$, are characterized by the first-order conditions

$$
\frac{\partial E U}{\partial X_{i j k}}=E U_{w}\left(p_{j} * f_{M i j k}-w_{k}\right)=0
$$

The second-order conditions are satisfied under risk aversion and a quasi-concave production function (Isik 2004). The optimal input mix is given by:

$$
X_{i j k}^{*}=X_{i j k}^{*}\left(p_{j}, w_{k}, U \mid A_{i}, Z_{i}\right)
$$

And the optimal output mix, depending on $\left(X_{i j k}^{*}\right)$ is defined as:

$$
\left.Q_{i j}^{*}=f\left(X_{i j 1}^{*}, \ldots \ldots X_{i j k}^{*}\right) \mid A_{i}, Z_{i}\right)
$$

\subsection{Determinants of choice of crops}

To determine the factors affecting a farmer's choice of crops, we derive the equivalent wealth or income from the expected utility (Rahman, 2008):

$$
E_{i}=E\left(W_{0}+\pi_{i}\left(Q, X, p, w \mid A_{i}, Z_{i}\right)\right.
$$

This equivalent wealth or income in a single decision making period is composed of net farm earnings (profits) from crop production and initial wealth that is 'exogenous' to the crop choices $\left(W_{0}\right)$, such as farm capital assets and livestock resources carried over from earlier period. 
Under the assumption of perfect market, farm production decisions are made separately from consumption decisions and the household maximizes net farm earnings (profits) subject to the technology and expenditure constraints (Benin et al. 2004). Therefore, production decision of the farms, such as crop choices, are driven by net returns (profits), which are determined only by input and output prices, farm physical characteristics and socio-economic characteristics of the farm household (Benin et al. 2004). Therefore, the optimal choice of the household can be reexpressed as a reduced form function of input and output prices, market wage, farm size, initial wealth, and socio-economic characteristics of the farms (Rahman, 2008):

$$
h_{i}^{*}=h_{i}^{*}\left(p_{j}, w_{k}, Z_{i}, A_{i}, W_{0 i}\right)
$$

Eq. (8) forms the basis for econometric estimation to examine the factors affecting diversity of crops on individual farms, an outcome of choices made in a constrained optimization problem.

After developing the model for the individual farmers, we extend the model to the regional level. The key assumption is that the factors affecting choice of crops at the individual farm household level in a given period of time can be applied to identify determinants of land area allocated to various crops at the regional level (which essentially represents combined action of individual farmer's responses in each region):

$$
D_{r t}=D_{r t}\left(\alpha_{r j t}^{*}\left(p_{j r t}, w_{k r t}, Z_{r t}, A_{r t}, W_{0 r t}\right)\right)
$$

where D represents the Shannon index of crop diversity at the regional level, $r$ represents the rth region $(\mathrm{r}=1,2,3, \ldots 17)$ and $\mathrm{t}$ represents time $(\mathrm{t}=1,2, \ldots 18)$.

We expect signs of the variables to correspond to those expected to hold at the farm household level analysis. That is positive influence of non-cereal crop price rises on crop diversity, positive influence of input price rises that are largely used for cereal monoculture (i.e., fertilizers) to trigger shift in cropping portfolio, positive influence of farm size, infrastructure and 
services (e.g., irrigation, extension and R\&D expenditure), and other measures of wealth (e.g., livestock resource) on crop diversity.

\subsection{Data}

The data used for the analysis are constructed from various sources. The principal data sector are taken from various issues of the Statistical Yearbook of Bangladesh, which reports land area, production and yield of all major crops covering the period 1990-2008 and 2011 (BBSa, various issues), agricultural censuses of Bangladesh 1983-1984, 1996 and 2008 (BBSb, various issues) and population censuses of Bangladesh 1991, 2001 and 2011 (BBSc, various issues). A total of 17 regions/greater districts are used for the analysis ${ }^{1}$.

\section{Dependent Variable: Shannon index of crop diversity}

The dependent variable is the Shannon index which was adapted from the ecological indices of spatial diversity in species. Evenness, which combines both richness and relative abundance concept, is measured by a Shannon index. Shannon's diversity index is frequently used in the determination of landscape diversity (e.g., Rahman, 2010; Benin et al., 2004) because of its indisputable advantage in obtaining numeric values that can be easily compared (Dusek and Popelkova, 2012). One limitation of Shannon index is its inability to express spatial distribution of patches within an area (Dusek and Popelkova, 2012) which in our case is not a major issue as we are using data at the regional level. It should also be noted that Shannon index is used as a relative index with higher value indicating higher diversity (Dusek and Popelkova, 2012).

\footnotetext{
${ }^{1}$ Although Bangladesh now has 64 districts, most time-series data are largely available at the greater district level (which was the original districts prevailed until 1981) and we are naming them as regions in this study.
} 


\section{Explanatory variables: socio-economic factors}

Independent variables are operational measurements of the vectors shown in the right hand side of Eq. (9). The various variables are defined and constructed as follows:

\begin{tabular}{|c|c|}
\hline $\begin{array}{l}\text { Area under different } \\
\text { crops }\end{array}$ & $\begin{array}{l}\text { Area (in thousand hectares) under major and crop groups is } \\
\text { included. This includes all seasons and varieties of rice (Aus, } \\
\text { Aman, and Boro - the pre-monsoon, monsoon and dry winter } \\
\text { seasons), wheat (includes maize, barley, cheena, and other minor } \\
\text { cereals), jute, sugarcane, pulses (includes gram, mung, mashkalai, } \\
\text { lentil, and khesari), oilseeds (includes mustard and til) vegetables } \\
\text { (includes potatoes, arum, bean, cabbage, cauliflower, cucumber, } \\
\text { jhinga, bitter gourd, brinjal, okra, patal, puisak, pumpkin, radish } \\
\text { and water gourd), and spices (chilli, garlic, ginger, onion and other } \\
\text { minor spices) for each of the } 17 \text { regions (greater districts). }\end{array}$ \\
\hline $\begin{array}{l}\text { Shannon index of crop } \\
\text { diversification }\end{array}$ & $\begin{array}{l}\text { To analyse crop diversity, the Shannon index which measures the } \\
\text { evenness and relative diversity is used. D=- } \sum \alpha_{j}^{*} \ln \alpha_{j}, D \geq 0 \text {, } \\
\text { where } \alpha_{j}=\text { area share occupied by the jth crop in A (Gross Cropped } \\
\text { Area). Higher value of index denotes higher diversity. }\end{array}$ \\
\hline Labour stock per farm & $\begin{array}{l}\text { Agricultural population (in thousands) for each region is used. This } \\
\text { was then divided by the number of farms in each region. Usable } \\
\text { information on agricultural population appeared in agricultural } \\
\text { censuses 1983-84, } 1996 \text { and 2008. Although definitions of } \\
\text { 'agricultural population' across periods is likely to vary, }\end{array}$ \\
\hline
\end{tabular}




\begin{tabular}{|c|c|}
\hline & $\begin{array}{l}\text { nevertheless, this is a far closer measure of labour (both adult male } \\
\text { and female) engaged in the sector than arbitrarily allocating all } \\
\text { rural adult male population as labour input as done by previous } \\
\text { studies. The data for the inter-census years were constructed using } \\
\text { a standard linear trend extrapolation model. }\end{array}$ \\
\hline $\begin{array}{l}\text { Land area }=\text { gross } \\
\text { cropped area }\end{array}$ & $\begin{array}{l}\text { Area (in thousand hectares) under all the crops mentioned above is } \\
\text { considered as the land area under cultivation or the gross cropped } \\
\text { area. This measure of land area allows for changes in cropping } \\
\text { intensity. Also, this measure of land area covers more than } 98 \% \text { of } \\
\text { the gross cropped area of the country as only fruits and orchards } \\
\text { are left out. }\end{array}$ \\
\hline $\begin{array}{l}\text { Livestock resources per } \\
\text { farm }\end{array}$ & $\begin{array}{l}\text { Number of draft animals (i.e., cattle and buffaloes) is estimated } \\
\text { using linear trend extrapolation from actual counts available in the } \\
\text { agricultural censuses of } 1983-84,1996 \text { and } 2008 . \text { This was then } \\
\text { divided by the number of farms in each region also computed from } \\
\text { the available censuses. The data for the inter-census years are } \\
\text { constructed using a standard linear trend extrapolation model. }\end{array}$ \\
\hline Crop output price & $\begin{array}{l}\text { Prices of major crop groups were used (see details of construction } \\
\text { below). }\end{array}$ \\
\hline Fertilizer price indices & $\begin{array}{l}\text { Price indices of three major fertilizers, namely, Urea, Triple Super } \\
\text { Phosphate (TSP) and Muriate of Potash (MP) were used. }\end{array}$ \\
\hline Irrigation & Proportion of total land area (above) under irrigation. The total \\
\hline
\end{tabular}




\begin{tabular}{|c|c|}
\hline & $\begin{array}{l}\text { area (in acres or hectares) under irrigation always appears in } \\
\text { various Yearbooks of Statistics of Bangladesh and is easy to } \\
\text { compute. }\end{array}$ \\
\hline Average farm size & $\begin{array}{l}\text { Average farm size (ha per farm) is taken from the agricultural } \\
\text { censuses } 1983-84,1996 \text { and } 2008 . \text { The data for the inter-census } \\
\text { years are constructed using a standard linear trend extrapolation } \\
\text { model. }\end{array}$ \\
\hline Average literacy rate & $\begin{array}{l}\text { Average literacy rate of population aged } 7 \text { years and above is taken } \\
\text { from Bangladesh Population censuses of 1991, } 2001 \text { and 2011. The } \\
\text { data for the inter-census years were constructed using a standard } \\
\text { linear trend extrapolation model. }\end{array}$ \\
\hline$R \& D$ expenditure & $\begin{array}{l}\text { Research and Development }(R \& D) \text { expenditure data is converted to } \\
\text { a series involving a time-lag in order to take account of the time } \\
\text { required for the technology generated by the research system to } \\
\text { reach the farmers for adoption. In order to take the lag into } \\
\text { account, the weighted sum of research expenditures over a period of } \\
14 \text { years is used. The research variable is constructed as } \Sigma W_{t-i} R_{t-i} \\
\text { where } W_{i} \text { is a weight and } R_{t-i} \text { is research investment in year } t-i \\
\text { measured at constant } 1984-85 \text { prices. The weight for the current } \\
\text { year research expenditure is zero, for a one year lag the weight is } \\
0.2, \text { while for a } 2 \text { year lag it is } 0.4 \text {, and so on (for details, see Dey } \\
\text { and Evenson, 1991). }\end{array}$ \\
\hline
\end{tabular}




\begin{tabular}{|l|l|}
\hline Extension Expenditure & $\begin{array}{l}\text { Total extension expenditure incurred by the MoA and/or the } \\
\text { Department of Agricultural Extension (in million taka) at constant } \\
1984-85 \text { prices is used. This was then divided by the number of } \\
\text { farms to derive the required variable. }\end{array}$ \\
\hline Total rainfall & Total rainfall measured in mm for each region. \\
\hline Temperature variability & This variable is measured as the difference between maximum and \\
& minimum average monthly temperature for each region. \\
\hline
\end{tabular}

\section{Explanatory variables: Input and output prices}

Construction of input and output prices for each region proved quite difficult as prices for some crops are reported at the divisional level ${ }^{2}$, some are reported only at the national level and there are missing years for some prices. Specifically, jute, sugarcane and fertilizer prices were reported at the national levels only while other prices were available for divisional levels. The missing year prices were interpolated using a linear trend model. Also, prices of pulses, oilseeds, spices and vegetables were constructed by taking average of individual crops in each group. Specifically, pulse price is the mean of the aggregate prices of gram, mung, lentil, and mashkalai. Spice price is the mean of the aggregate prices of chilli, onion, turmeric, ginger and garlic. Vegetable price is the mean of the aggregate prices of cabbage, cauliflower, jhinga, bitter gourd, brinjal, pumpkin, okra, patal, and spinach. All input and crop prices were normalized by the rice price. Hence, these are relative prices of inputs and outputs. The reason for doing this is twofold. First, it is assumed that the shift in the relative prices of major inputs (i.e., fertilizers) and

\footnotetext{
${ }^{2}$ Division is a higher level of aggregation of administrative region. Currently, there are six divisions encompassing 17 greater districts or 64 new districts of Bangladesh.
} 
other crops will induce farmers to diversify their crop portfolio from rice monoculture. Second, since the ratio is unit free, we have avoided collinearity that may arise from specifying close substitutes (e.g., cabbage and cauliflower) as well as measurement problems that arises from indexing individual crop prices with a constant base year to reflect real prices changes. An advantage of using prices at divisional or national level is that the prices faced by individual farmers or at the regional level are exogenous, as they essentially are price takers, and hence avoid the problem of endogeneity of price variables in the modelling structure.

Apart from incorporating the input and output prices, the justification for inclusion of other variables are as follows: Land is the scarcest resource in Bangladesh, and farm size largely determines the level and extent of income to be derived from farming. Land also serves as a surrogate for a large number of factors as it is a major source of wealth and influences decision to choose crops. Also, greater farm areas can be allocated among more crops (Benin et al. 2004). Hence, the average farm size (to represent wealth) was incorporated to test its independent influence on decisions regarding crop diversification.

Farmers in Bangladesh are not only land poor, but also resource poor. In the absence of any reliable account of farm capital assets, we could not include this. However, livestock is an important measure of wealth and is an integral component in farming. Rahman (2008) noted that a reduction in livestock resources is positively related to crop diversity at the farm level because growing non-cereal do not require extensive draft power support. We include this variable to check whether such result hold at the regional level as well.

Access to modern irrigation facilities is an important pre-requisite for growing HYV rice, particularly HYV Boro rice (dry winter season). Lack of access to modern irrigation facilities has been identified as one of the principal reasons for stagnation in the expansion of HYV rice area 
(Rahman and Thapa 1999; Mahmud, Rahman and Zohir 1994). In 2010, only 44\% of total rice area was irrigated in 2010 (BBS, 2011). Also, irrigation may decrease diversity through uniform moisture conditions (Benin et al. 2004).

Use of farmers' education level as explanatory variable in technology adoption studies is common (e.g., Rahman, 2009). The education variable was used as a surrogate for a number of factors. At the technical level, access to information as well as capacity to understand the technical aspects and profitability related to different crops may influence crop production decisions. Therefore, the average literacy rate was incorporated to reflect this.

$\mathrm{R} \& \mathrm{D}$ is an important element in disseminating modern technology and production knowhow to farmers. The capacity to promote agricultural growth hinges largely on the effectiveness of the R\&D activities and achievements. Conventionally, the R\&D activities in Bangladesh are largely concentrated on developing HYV rice varieties to the neglect of most other crops. Among the non-cereals, modern technology is only well established in potato cultivation (Mahmud, Rahman and Zohir 1994). The Bangladesh Agricultural Research Institute (BARI) is entrusted with the responsibility of developing HYV varieties of all cereal and noncereal crops except rice and jute. To date, a total of 131 improved varieties of various cereal and non-cereal crops have been developed and released by BARI (Hossain et al. 2006). The thrust in developing and releasing improved varieties by BARI actually gained momentum from mid1990s, a complementary effort to government's emphasis on promoting crop diversification in its FFYP document (1997-2002). However, there is a need to examine the impact of these new releases on farmers' portfolios of crop choices. Therefore, the total R\&D expenditure variable is included to examine its effect on crop diversity. 
Agricultural extension can be singled out as one of the important sources of information dissemination directly relevant to agricultural production practices, particularly in nations like Bangladesh where farmers have very limited access to information. This was reinforced by the fact that studies found a significant influence of extension education on adoption of landimproving technologies (e.g., Solis et al., 2007). Therefore, the total expenditure on extension per farm was incorporated to account for its influence on crop choices.

Climate change has been one of the hottest debates in all sectors of the economy and Bangladesh is earmarked as the country most vulnerable to climate change. Therefore, two climate change variables: variability in total annual rainfall and average maximum temperature were included to see their influences on decision regarding choice of crops.

\section{$2.4 \quad$ Regression Structure}

In order to identify the determinants of regional crop diversity, we use the Generalised Least Squares (GLS) Random Effects model for panel data after conducting appropriate tests (for details, see section 3.2). We use this approach in order to account for any systematic effect of the regions as well as time-varying effects of the explanatory variables. The basic model is specified as follows:

$$
\ln D_{r t}=a_{r t}+b_{r t} \ln p_{t}+c_{r t} \ln w_{t}+d_{r t} \ln Z_{t}+u_{i}+e_{r t}
$$

where $D$ represents the Shannon index of evenness, $p$ is a vector of output prices, $w$ is a vector of input prices, $Z$ is a vector of socio-economic characteristics of the regions, $e$ is the error term controlling for the unobserved factors and/or random noise, and $a, b, c$ and $d$ are the parameters to be estimated, $u_{i}$ is the unit specific random element distributed as $I I D\left(0, \sigma_{u}^{2}\right)$ and is assumed to be independent of $\varepsilon_{i t}$ and $p_{\mathrm{t}}, w_{\mathrm{t}}, \mathrm{Z}_{\mathrm{t}}$, and $\varepsilon_{i t}$ is distributed as $I I D\left(0, \sigma_{\varepsilon}^{2}\right)$; $\ln$ is the natural logarithm. The empirical model is presented in double log specification (e.g., Singh et al., 2006) 
which provides us with two advantages: (a) it allows for possible non-linearity of the underlying model with coefficients being linear in parameters, and (b) the coefficients can be directly read as elasticities, i.e, diversity elasticities. Parameters were estimated using STATA V10 software program (StataCorp 2010).

\section{Results}

\subsection{Trends and levels of crop diversity}

Average annual compound growth rates were computed in order to determine the rate of change of the variable of interest. The growth rates were computed using semi-logarithmic trend function: $\ln Y=\alpha+\beta T$, where $Y$ is the target variable, $T$ is time, $\ln$ is natural logarithm, and $\beta$ is the growth rate. The assumption here is that the estimated growth rate is constant over the time period which is a reasonable assumption as the time period is only 18 years.

Table 1 presents the growth in cropped area by regions of Bangladesh (i.e., greater districts) for a 19 year period (1990-2008). It is clear from Table 1 that except for HYV rice, spices and vegetables, all other crop groups experienced a decline. Even the expansion of wheat and maize grouped under minor cereals could not reverse the decline in growth rate in this category. Also, the level of decline and/or growth is highly variable across regions. The market prices of all non-cereal crops have risen over time, but even then we see growth in only spices and vegetables, but not amongst oilseeds, pulses and cash crops such a jute and sugarcane. The highest rate of decline is in pulse crops which raise concern regarding sustainability of the cropping system in Bangladesh as pulses are leguminous crops which fix nitrogen in the soils. Table 1 also confirms that significant differences exist across regions with respect to share of each crop group in GCA, thereby justifying the need to conduct regional level analysis. 
Table 2 presents the level of crop diversity in Bangladesh agriculture by regions and Figure 1 presents the overall trend in crop diversity for the period under consideration. Overall, crop diversity has steadily declined in Bangladesh. Also, most of the regions experienced a decline in its initial level of diversity except Khulna, Sylhet and Faridpur. Khulna is a region with explosion of gher farming (i.e., prawn-fish-rice joint culture) where farmers also grow vegetables at the boundaries of the gher to maximize returns. Sylhet is a hilly region historically famous for tea production and non-cereals (mainly vegetables) as growing three seasons of rice is not feasible due to lack of irrigation facilities. Faridpur is a low lying area which has diversified into non-cereals because of lack of expansion of irrigation facilities. The level of diversity is also highly variable across region with significant differences. The initial level of crop diversity in 1990 was highest in Kushtia followed by Dhaka and Chittagong Hill Tracts, but during the terminal year of 2008, the highest diversity is in Faridpur followed by Pabna. Similarly, the share of non-cereals (i.e., excludes rice, wheat, maize and other minor cereals) in GCA is highly variable across regions with significant differences. Overall, a substantial $30.8 \%$ of GCA is under non-cereals which indicate that the cropping system in Bangladesh is still diverse. It should be noted that Sylhet is a region famous for tea growing which is not captured in this dataset. The results challenge the conventional notion that cropping system in Bangladesh is strictly concentrated in producing cereals, mainly rice.

\subsection{Determinants of crop diversity}

In this section, we concentrate on examining determinants of crop diversity at the regional level in Bangladesh over time. Table 3 presents the parameter estimates of Eq (10) using the GLS Random Effects estimation procedure for panel data which accounts for any systematic effect of the regions as well as time varying effects of the variables used in the regression. The use of 
cluster robust standard error option also accounts for mis-specification of the model as well. Two Hausman tests were done in order to determine consistency and efficiency of GLS random effects estimators. The null-hypothesis that 'the coefficients are consistent and efficient in random effects model as compared with fixed effects model' cannot be rejected, and hence we chose the random effects model as it is more efficient (see last panel of Table 3). Table 3 also presents Ordinary Least Squares estimators with panel corrected standard errors and GLS fixed effects model with cluster robust standard errors for comparison, although we discuss only the results of GLS random effects model next.

Overall, the fit is quite satisfactory as $56 \%$ of the coefficients on the regressors are significantly different from zero at the $10 \%$ level at least. The parameters $\sigma_{\mathfrak{u}}$ and $\sigma_{\varepsilon}$ are the sources of variations, the former is from the heterogeneity of regions and the latter is from idiosyncratic errors or noise and $\rho$ is the intraclass correlation or the fraction of variance due to $\mathrm{u}_{\mathrm{i}}$. The model diagnostics reveal that regional heterogeneity and idiosyncratic errors explain very little about the variation in crop diversify reflected by low values of these two parameters. Instead, variation in regional crop diversity is explained largely by the explanatory variables used in the regression which is confirmed by the Wald $\chi^{2}$ statistics. The Wald $\chi^{2}$ tests that the coefficients on the regressors are jointly zero, which is strongly rejected at $1 \%$ level, implying that our model specification is significant. Another assessment is the goodness of fit demonstrated by the three values of the R-squared, which are correlations squared of the second round regressions. These values are quite reasonable.

Among the input prices, we see that a rise in the relative price of urea fertilizer will significantly increase crop diversity with an elasticity value of 0.35 . A one percent increase in the relative price of urea will increase crop diversity by $0.4 \%$. The implication is that if the urea 
price increases then farmers will switch to non-cereal crops as urea is used largely to produce rice in Bangladesh. The influences of other fertilizer prices are insignificant. There may be two reasons for this. First, the prices of these two fertilizers are largely stable. Second, farmers in Bangladesh tend to concentrate on using urea fertilizer as it provide visible plant growth, and also recommended dosage for urea is much higher than the other two fertilizers. Therefore, a change in the relative price of urea triggers change in the decision making process as more cash outlays are involved than a change in the relative price of the other two fertilizers.

Among the crop prices, increase in the relative price of vegetables will significantly increase crop diversity with an elasticity value of 0.22 . This is expected as revenue earned from vegetables are significantly higher than producing cereals (Rahman, 2009) This may explain observed increase in the area allocated to various vegetables in GCA over time (see Table 2) with corresponding rise in the revenue earned from exporting vegetables from Bangladesh in recent years. The rise in relative price of pulses and sugarcane will reduce diversity which is at contrast with expectation.

The influence of the set of socio-economic factors in determining crop diversity is very strong and varied. We see that increases in extension expenditure per farm, labour per farm, average farm size and irrigation and a reduction in livestock capital significantly increase crop diversity consistent with expectation. Livestock serves as a source of wealth as well as draft power in farming mainly for rice production. Therefore, a reduction in livestock resource motivates farmers to move away from rice monoculture consistent with the findings of Rahman (2008). Since non-cereal crop farming is more labour intensive, availability of labour enables farmers to diversify their cropping portfolio. An increase in literacy rate significantly reduces crop diversity. This is because education allows farmers to divert their time input away from 
agriculture to non-agricultural sector (Rahman and Shankar, 2009). The influences of R\&D expenditure and climatic factors (rainfall variability and average maximum temperature) are insignificant. As mentioned earlier, R\&D investment in Bangladesh is focused largely on cereals. Therefore, lack of its influence in promoting crop diversity is possible.

\section{Conclusions and policy implications}

The aim of this study is to examine trends in area allocated to various crops, the level of crop diversity by region, and identify its determinants covering a 19 year period (1990-2008). Results demonstrate that other than area under HYV rice, vegetables and spices, all other crop areas experienced significant decline at variable rates over time. The level of crop diversity over time declined for most regions except Khulna, Sylhet and Faridpur. Significant differences in crop diversity as well as share of each crop group in GCA exist across regions. A host of price and non-price factors significantly influence farmers' decision to diversify. An increase in the relative prices of urea fertilizer and vegetables will significantly increase crop diversity. In other words, a rise in relative prices of urea and vegetables will shift farmers to diversify their cropping portfolio. A decline in wealth in terms of livestock induces farmers to switch to noncereals that are not heavily dependent on draft power as these are grown on small scale by individual farms. Switching to a diversified cropping system is labour intensive and our results show that an increase in labour stock per farm allows farms to diversify. Increase in irrigation, average farm size and extension services also significantly increase crop diversity.

The policy implications are clear. The government should increase investment in extension expenditure and irrigation infrastructure as these policy amenable instruments will significantly increase crop diversity. Also, price policies aimed at increasing vegetable prices will increase crop diversification which in turn will increase foreign exchange earnings for the 
economy. Ali (2004) also highlighted that investment in research and extension system and policy incentives geared towards high value crops (e.g., vegetables) not only make them internationally competitive, but will also improve earnings and productivity of the sector which was also echoed by Joshi, Birthal and Minot (2006). In Bangladesh, 69\% of area under vegetables were irrigated as compared to $44 \%$ of rice area in 2010 (BBS, 2011) which establishes the need to increase investment in irrigation infrastructure to promote crop diversity. 


\section{References}

Ali, M. 2004. Agricultural Diversification and International Competitiveness (Ed Ali, M). Asian Productivity Organization, Tokyo, Japan. Available @ http://www.apotokyo.org/publications/files/agr-03-ad ic.pdf (Accessed 12/11/2013).

Ali, M., Abdullah, O. Farooq. 2004. Diversification with vegetables to improve competitiveness in Asia. In Ali, M (ed) Agricultural diversification and international competitiveness. Asian Productivity Organization, Tokyo, Japan. pp. 51-82.

BBSa (various issues). Yearbook of Agricultural Statistics of Bangladesh, 1990 through 2011. Dhaka: Bangladesh Bureau of Statistics.

BBSb (various issues). Population Census of Bangladesh, 1991, 2001 and 2011. Dhaka: Bangladesh Bureau of Statistics.

BBSc. Census of agriculture and livestock in Bangladesh, 1983-84, 1996 and 2008. Dhaka: Bangladesh Bureau of Statistics.

Benin, S., M. Smale, M., J. Pender, B. Gebremedhin, and S. Ehui. 2004. "The Economic Determinants of Cereal Crop Diversity on Farms in the Ethiopian Highlands". Agricultural Economics 31:197-208.

Bhattacharya, R. 2008. "Crop diversification: a search for an alternative income of the farmers in the state of West Bengal in India". International Conference on Applied Economics, ICOAE, 2008. Available@@ http://kastoria.teikoz.gr/icoae2/wordpress/wpcontent/uploads/articles/ 2011/10/012-2008.pdf (Accessed 12/11/2013).

Dey, M., and R.E. Evenson. 1991. The economic impact of rice research in Bangladesh. BRRI/IRRI/BARC, Dhaka, Bangladesh. 
Dusek, R. and R. Popelkova. 2012. Theoretical view of the Shannon index in the evaluation of landscape diversity. AUC Geographica, 47: 5-13.

Hossain, M.S., M.M. Rahman, M. Harun-ur-Rashid, A.T.M. Farid, M.A. Quayyum, M. Ahmed, M.S. Alam, and K.M.S.U. Hussain. 2006. Krishi Projukti Hatboi (Handbook of Agrotechnology). $4^{\text {th }}$ Edition. Gazipur: Bangladesh Agricultural Research Institute.

Husain, A.M.M., M. Hossain, and A. Janaiah. 2001 Hybrid Rice Adoption in Bangladesh: Socioeconomic Assessment of Farmers' Experiences. BRAC Research Monograph Series No. 18. Dhaka: BRAC.

IMF, 2005. Bangladesh Poverty Reduction Strategy Paper. IMF Country Report No. 04/410. 2005. Washington, D.C.

Isik, M. 2004. "Environmental Regulation and the Spatial Structure of the US Dairy Sector". American Journal of Agricultural Economics, 86: 949-962.

Joshi, P.K., P.S. Birthal and N. Minot. 2006. Sources of agricultural growth in India: Role of diversification towards high-value crops. MTID Discussion Paper \#98. International Food Policy Research Institute, Washington, D.C.

Kazal, M.M.H., S. Rahman, M.J. Alam, and S.T. Hossain. 2013. Financial and economic profitability of selected agricultural crops in Bangladesh. NFPCSP-FAO Research Grant Report \#05/11. Dhaka, Bangladesh. July 2013.

Mahmud, W., S.H. Rahman, and S. Zohir. 1994. Agricultural Growth Through Crop Diversification in Bangladesh. Food Policy in Bangladesh Working Paper No. 7. Washington, D.C. International Food Policy Research Institute.

MoA. 1989. Crop Diversification Program for the Fourth Five-Year Plan of Bangladesh. Dhaka: Agriculture Division, Ministry of Agriculture. 
PC, 1998. The Fifth Five Year Plan (1997-2002). Ministry of Planning, Government of Bangladesh, Dhaka. 1998.

PC, 2011. The Sixth Five Year Plan (2011-2015). Ministry of Planning, Government of Bangladesh, Dhaka. 2011.

Rahman, S. 2000. "Women's Employment in Bangladesh Agriculture: Composition, Determinants and Scope". Journal of Rural Studies, 16: 497-507.

Rahman, S. 2008. "The economic determinants of crop diversity on farms in rural Bangladesh". Journal of International Agricultural Trade and Development, 5: 51-70.

Rahman, S. 2009. "Whether crop diversification is a desired strategy for agricultural growth in Bangladesh”. Food Policy, 34: 340-349.

Rahman, S. 2010. Six decades of agricultural land use change in Bangladesh: effects on crop diversity, productivity, food availability and the environment, 1948-2006. Singapore Journal of Tropical Geography, 31: 254-269.

Rahman, S., and B. Shankar. 2009. "Profits, supply and HYV adoption in Bangladesh". Journal of the Asia Pacific Economy, 14: 73-89.

Rahman, S., and G.B. Thapa. 1999. "Environmental Impacts of Technological Change in Bangladesh Agriculture: Farmers' Perceptions and Empirical Evidence”. Outlook on Agriculture, 28: 233-238.

Singh, A. 2011. Diversification in agriculture. @www.eoearth.org/view/article/151757 (Accessed February 15, 2014).

Singh, N.P., R. Kumar, and R.P. Singh. 2006. Diversification of Indian agriculture: composition, determinants and trade implications. Agricultural Economics and Research Review, 19: 2336. 
Solis, D., B.E. Bravo-Ureta, and R.E. Quiroga. 2007. "Soil conservation and technical efficiency among hillside farmers in Central America: a switching regression model". Australian Journal of Agricultural and Resource Economics, 51: 491-510.

Winters, P., R. Cavatassi, and L. Lipper. 2006. Sowing the seeds of social relations: The role of social capital in crop diversity. ESA Working Paper No. 6-16. FAO, Rome. pp. 1-40. 
Table 1. Trends in area allocated to various crops in Bangladesh (1990-2008).

\begin{tabular}{|c|c|c|c|c|c|c|c|c|c|}
\hline \multirow[t]{2}{*}{ Regions } & \multicolumn{9}{|c|}{ Average annual compound growth rate } \\
\hline & Local rice & HYV rice & Minor cereals & Pulses & Oilseeds & Spices & Jute & Sugarcane & Vegetables \\
\hline Barisal & $-0.010 * * *$ & $0.069 * * *$ & $-0.028 *$ & $-0.062 * * *$ & $-0.117 * * *$ & $0.043 * * *$ & $-0.012 *$ & $-0.094 * * *$ & $0.040 * * *$ \\
\hline Bogra & $-0.075 * * *$ & $0.024 * * *$ & -0.008 & $-0.145 * * *$ & $0.060 * * *$ & $-0.019 * * *$ & $-0.058 * * *$ & $-0.034 * * *$ & $0.086 * * *$ \\
\hline Chittagong & $-0.075 * * *$ & $0.021 * * *$ & $103 * * *$ & $-0.066 * * *$ & $-0.020 * * *$ & $0.031 * * *$ & $\mathrm{NG}$ & $0.012 * * *$ & $.049 * * *$ \\
\hline $\begin{array}{l}\text { Chittagong Hill } \\
\text { Tracts }\end{array}$ & $-0.040 * * *$ & $0.050 * * *$ & -0.013 & $-0.054 * * *$ & $-0.098 * * *$ & $0.074 * * *$ & $-0.226 * * *$ & $0.017 * * *$ & $0.065 * * *$ \\
\hline Comilla & $-0.082 * * *$ & $0.020 * * *$ & $-0.038 * * *$ & $-0.069 * * *$ & $-0.081 * * *$ & $0.027 * * *$ & $-0.060 * *$ & 0.005 & $0.027 * * *$ \\
\hline Dhaka & $-0.082 * * *$ & $0.044 * * *$ & $-0.026 * * *$ & $-0.085 * * *$ & 0.029 & $0.050 * * *$ & $-0.047 * * *$ & $-0.021 * * *$ & $.042 * * *$ \\
\hline Dinajpur & $-0.087 * * *$ & $0.062 * * *$ & $0.022 * * *$ & $-0.130 * * *$ & -0.017 & $0.038 * * *$ & $-0.023 * * *$ & $-0.005 * * *$ & $066 * * *$ \\
\hline Faridpur & $-0.058 * * *$ & $0.057 * * *$ & -0.005 & $-0.060 * * *$ & $-0.046 * * *$ & $0.064 * * *$ & $0.027 * * *$ & $-0.027 * * *$ & $0.043 * * *$ \\
\hline Jessore & $-0.099 * * *$ & $0.035 * * *$ & $-0.023 * *$ & $-0.072 * * *$ & $-0.016 * *$ & $0.063 * * *$ & -0.013 & $-0.030 * * *$ & $0.045 * * *$ \\
\hline Khulna & $-0.063 * * *$ & $0.065 * * *$ & $-0.041 * * *$ & $-0.044 * *$ & -0.012 & $0.027 * * *$ & $-0.025 * *$ & $-0.012 *$ & $0.054 * * *$ \\
\hline Kushtia & $-0.105 * * *$ & $0.048 * * *$ & $0.009 * * *$ & $-0.065 * * *$ & $0.031 * * *$ & $0.087 * * *$ & 0.010 & $-0.025 * * *$ & $0.058 * * *$ \\
\hline Mymensingh & $-0.082 * * *$ & $0.045 * * *$ & $-0.081 * * *$ & $-0.121 * * *$ & $-0.069 * * *$ & $0.058 * * *$ & $-0.058 * * *$ & $-0.029 * * *$ & $0.039 * * *$ \\
\hline Noakhali & $-0.025 * * *$ & $0.013 * * *$ & $-0.078 * * *$ & $-0.075 * * *$ & $-0.098 * * *$ & $0.038 * * *$ & $-0.073 * * *$ & $-0.035 * * *$ & $0.040 * * *$ \\
\hline Pabna & $-0.057 * * *$ & $0.054 * * *$ & $-0.027 * *$ & $-0.053 * * *$ & -0.001 & $0.105 * * *$ & -0.006 & $0.012^{* *}$ & $0.009 * *$ \\
\hline Rajshahi & $-0.107 * * *$ & $0.051 * * *$ & $0.023 * * *$ & $-0.083 * * *$ & -0.008 & $0.092 * * *$ & -0.039 & -0.004 & $0.075 * * *$ \\
\hline Rangpur & $-0.108 * * *$ & $0.043 * * *$ & $-0.011 * *$ & $-0.091 * * *$ & $-0.037 * * *$ & $0.019 * * *$ & $-0.045 * *$ & $-0.043 * * *$ & $0.100 * * *$ \\
\hline Sylhet & $-0.042 * * *$ & $0.043 * * *$ & $-0.104 * * *$ & $-0.053 * * *$ & $-0.071 * * *$ & $0.034 * * *$ & $-0.042 *$ & 0.003 & $0.024 * *$ \\
\hline Bangladesh & $-0.063 * * *$ & $0.038 * * *$ & $-0.016 * * *$ & $-0.068 * * *$ & $-0.033 * * *$ & $0.049 * * *$ & $-0.038 * * *$ & $-0.017 * * *$ & $0.051 * * *$ \\
\hline & & & & & & & & & \\
\hline & $54.26 * * *$ & 41.63 & $258.75^{* * *}$ & $87.45^{* * *}$ & $59.27 * * *$ & $18.4 * * *$ & $50.13 * * *$ & $511.99 * * *$ & $38.69 *=$ \\
\hline
\end{tabular}

Note: $\quad \mathrm{NG}=$ not grown

$* * *=$ significant at $1 \%$ level $(\mathrm{p}<0.01)$

$* *=$ significant at $5 \%$ level $(p<0.05)$

$*=$ significant at $10 \%$ level $(\mathrm{p}<0.10)$ 
Table 2. Shannon index of crop diversity in regions of Bangladesh.

\begin{tabular}{|c|c|c|c|c|c|c|c|c|}
\hline Regions & $\begin{array}{l}\text { Mean index of } \\
\text { crop diversity }\end{array}$ & $\begin{array}{l}\text { Crop diversity } \\
\text { index in } 1990\end{array}$ & $\begin{array}{l}\text { Crop diversity } \\
\text { index in } 2008\end{array}$ & $\begin{array}{l}\text { \% change in } \\
\text { crop diversity } \\
\text { index in } 2008 \\
\text { from } 1990\end{array}$ & $\begin{array}{l}\text { Direction of } \\
\text { crop diversity } \\
\text { in } 2008 \text { from } \\
1990\end{array}$ & $\begin{array}{l}\text { Share of non- } \\
\text { cereal in GCA } \\
\text { in } 1990(\%)\end{array}$ & $\begin{array}{l}\text { Share of non- } \\
\text { cereal in GCA } \\
\text { in } 2008(\%)\end{array}$ & $\begin{array}{l}\text { Average share } \\
\text { of non-cereal } \\
\text { in GCA }(\%)\end{array}$ \\
\hline Barisal & 0.95 & 0.97 & 0.86 & -12.79 & $\downarrow$ & 16.98 & 6.21 & 13.89 \\
\hline Bogra & 1.06 & 1.27 & 0.85 & -49.41 & $\downarrow$ & 11.56 & 19.01 & 11.62 \\
\hline Chittagong & 0.88 & 0.93 & 0.75 & -24.00 & $\downarrow$ & 4.56 & 7.61 & 6.83 \\
\hline Chittagong Hill Tracts & 1.58 & 1.72 & 1.37 & -25.55 & $\downarrow$ & 43.96 & 28.53 & 39.77 \\
\hline Comilla & 1.33 & 1.43 & 1.07 & -33.64 & $\downarrow$ & 14.28 & 11.67 & 14.41 \\
\hline Dhaka & 1.59 & 1.76 & 1.38 & -27.54 & $\downarrow$ & 30.22 & 28.29 & 25.16 \\
\hline Dinajpur & 1.40 & 1.42 & 1.05 & -35.24 & $\downarrow$ & 12.57 & 14.68 & 12.79 \\
\hline Faridpur & 1.77 & 1.70 & 1.78 & 4.49 & $\uparrow$ & 31.85 & 43.30 & 34.20 \\
\hline Jessore & 1.44 & 1.62 & 1.13 & -43.36 & $\downarrow$ & 27.07 & 21.38 & 24.09 \\
\hline Khulna & 1.07 & 0.80 & 1.09 & 26.61 & $\uparrow$ & 7.90 & 8.83 & 9.33 \\
\hline Kushtia & 1.65 & 1.80 & 1.34 & -34.33 & $\downarrow$ & 30.48 & 27.78 & 29.83 \\
\hline Mymensingh & 1.30 & 1.38 & 1.05 & -31.43 & $\downarrow$ & 15.74 & 11.33 & 13.23 \\
\hline Noakhali & 1.07 & 1.03 & 0.99 & -4.04 & $\downarrow$ & 10.21 & 6.76 & 10.08 \\
\hline Pabna & 1.65 & 1.76 & 1.51 & -16.56 & $\downarrow$ & 24.96 & 26.96 & 22.23 \\
\hline Rajshahi & 1.35 & 1.50 & 1.13 & -32.74 & $\downarrow$ & 18.23 & 15.88 & 16.63 \\
\hline Rangpur & 1.27 & 1.39 & 0.96 & -44.79 & $\downarrow$ & 15.22 & 15.60 & 15.53 \\
\hline Sylhet & 0.88 & 0.75 & 0.80 & 6.25 & $\uparrow$ & 3.30 & 2.46 & 3.69 \\
\hline Bangladesh & 1.27 & 1.32 & 1.09 & -21.20 & $\downarrow$ & 18.77 & 17.42 & 17.84 \\
\hline \multicolumn{9}{|c|}{ Test for regional differences in Shannon index and average share of non-cereals in GCA (Generalized linear model with one way ANOVA) } \\
\hline F-statistic $(16,306)$ & $122.72 * * *$ & -- & -- & -- & -- & -- & -- & $218.60 * * *$ \\
\hline
\end{tabular}


Table 3. Determinants of crop diversity in Bangladesh

\begin{tabular}{|c|c|c|c|c|c|c|}
\hline \multirow[t]{2}{*}{ Variables } & \multicolumn{2}{|c|}{$\begin{array}{l}\text { OLS model with panel corrected } \\
\text { standard errors }\end{array}$} & \multicolumn{2}{|c|}{$\begin{array}{l}\text { Fixed effects GLS model with } \\
\text { robust standard errors }\end{array}$} & \multicolumn{2}{|c|}{$\begin{array}{l}\text { Random effects GLS model with } \\
\text { robust standard errors }\end{array}$} \\
\hline & Coefficients & z-value & Coefficients & z-value & Coefficients & Z-value \\
\hline Constant & -0.6798 & -0.32 & 2.9179 & 1.30 & $2.9516 * *$ & 2.24 \\
\hline \multicolumn{7}{|l|}{ Prices (Normalized by rice price) } \\
\hline In Urea & 0.1974 & 0.95 & $0.3592 * * *$ & 4.23 & $0.3517 * * *$ & 5.04 \\
\hline $\ln \mathrm{TSP}$ & -0.0612 & -0.73 & 0.0334 & 1.26 & 0.0319 & 1.10 \\
\hline $\ln \mathrm{MP}$ & $-0.1914 * *$ & -2.04 & -0.0420 & -1.50 & -0.0436 & -1.23 \\
\hline In Jute & $-0.1957 * * *$ & -3.02 & 0.0175 & 0.75 & 0.0146 & 0.68 \\
\hline In Sugarcane & 0.0576 & 0.20 & $-0.3224 * *$ & -2.37 & $-0.3094 * * *$ & -2.84 \\
\hline In Pulses & 0.0436 & 0.44 & $-0.1388 * * *$ & -3.93 & $-0.1380 * * *$ & -3.45 \\
\hline In Vegetables & $0.4733 * * *$ & 6.00 & $0.2176 * * *$ & 2.89 & $0.2169 * * *$ & 5.90 \\
\hline $\ln$ Spices & -0.1262 & -1.28 & -0.0210 & -0.54 & -0.0215 & -0.62 \\
\hline In Oilseeds & $-0.2577 * * *$ & -3.41 & -0.0088 & -0.75 & -0.0104 & -0.53 \\
\hline \multicolumn{7}{|l|}{ Socio-economic factors } \\
\hline In Extension expenditure per farm & $0.0843 * * *$ & 5.79 & $0.0530 * * *$ & 3.42 & $0.0532 * * *$ & 5.27 \\
\hline InAnimal power per farm & $-0.2168 * * *$ & -6.38 & $-0.1549 * *$ & -1.97 & $-0.1566 * * *$ & -4.52 \\
\hline In Labour per farm & $0.1189 * * *$ & 4.03 & 0.0774 & 0.79 & $0.0775 *$ & 1.80 \\
\hline In Share of irrigated area in GCA & $0.0782 * * *$ & 4.81 & $0.1332 * * *$ & 2.59 & $0.1299 * * *$ & 4.56 \\
\hline InAverage farm size & $0.1611 * * *$ & 4.12 & $0.1963 * * *$ & 2.50 & $0.1902 * * *$ & 4.09 \\
\hline In R\&D investment & 0.1094 & 0.85 & -0.0021 & -0.01 & -0.0092 & -0.10 \\
\hline In Average literacy rate & $-0.2731 * * *$ & -7.70 & $-0.5780 * * *$ & -3.33 & $-0.5625 * * *$ & -7.04 \\
\hline \multicolumn{7}{|l|}{ Climatic factors } \\
\hline In Rainfall variability & $-0.1967 * * *$ & -6.41 & -0.0037 & -0.23 & -0.0057 & -0.43 \\
\hline In Average maximum temperature & $0.6954 * * *$ & 4.99 & 0.0291 & 0.23 & 0.0404 & 0.54 \\
\hline \multicolumn{7}{|l|}{ Model diagnostics } \\
\hline R-sq within regression & -- & & 0.69 & & 0.68 & \\
\hline R-sq between regression & -- & & 0.26 & & 0.27 & \\
\hline
\end{tabular}




\begin{tabular}{|c|c|c|c|c|c|c|}
\hline \multirow[t]{2}{*}{ Variables } & \multicolumn{2}{|c|}{$\begin{array}{l}\text { OLS model with panel corrected } \\
\text { standard errors }\end{array}$} & \multicolumn{2}{|c|}{$\begin{array}{l}\text { Fixed effects GLS model with } \\
\text { robust standard errors }\end{array}$} & \multicolumn{2}{|c|}{$\begin{array}{l}\text { Random effects GLS model with } \\
\text { robust standard errors }\end{array}$} \\
\hline & Coefficients & z-value & Coefficients & z-value & Coefficients & z-value \\
\hline R-sq overall & 0.52 & & 0.31 & & 0.32 & \\
\hline Sigma_u & - & & 0.1989 & & 0.1940 & \\
\hline Sigma_e & - & & 0.0522 & & 0.0522 & \\
\hline Rho (fraction of variance due to $\mathrm{u}_{\mathrm{i}}$ ) & - & & 0.9356 & & 0.9325 & \\
\hline Wald Chi-squared (18 df) & $752.49 * * *$ & & & & & $653.26 * * *$ \\
\hline F-statistic $_{(18,288)}$ & -- & & $33.82 * * *$ & & -- & \\
\hline Model specification tests & & & & & & \\
\hline \multicolumn{4}{|c|}{$\begin{array}{l}\text { Hausman test (Fixed effects vs Random effects) } \\
\mathrm{H}_{\mathrm{O}}=\text { The difference in coefficients not systematic. } \\
\text { i.e., Random effects coefficients are consistent and efficient under } \mathrm{H}_{\mathrm{O}}\end{array}$} & $\begin{array}{l}\text { Wald Chi- } \\
\text { squared (18 df) }\end{array}$ & $23.00^{\mathrm{ns}}$ & $\begin{array}{r}\mathrm{H}_{\mathrm{O}} \text { cannot be } \\
\text { rejected (i.e., } \\
\text { Random effects } \\
\text { model is } \\
\text { appropriate) }\end{array}$ \\
\hline \multicolumn{4}{|c|}{$\begin{array}{l}\text { Hausman test (Between regression vs Random effects) } \\
\mathrm{H}_{\mathrm{O}}=\text { The difference in coefficients not systematic. } \\
\text { i.e., Random effects coefficients are consistent and efficient under } \mathrm{H}_{\mathrm{O}}\end{array}$} & $\begin{array}{l}\text { Wald Chi- } \\
\text { squared (18 df) }\end{array}$ & $13.62^{\text {ns }}$ & $\begin{array}{r}\mathrm{H}_{\mathrm{O}} \text { cannot be } \\
\text { rejected (i.e., } \\
\text { Random effects } \\
\text { model is } \\
\text { appropriate) }\end{array}$ \\
\hline
\end{tabular}

Note: $\quad * * *=$ significant at $1 \%$ level $(\mathrm{p}<0.01)$

$* *=$ significant at $5 \%$ level $(\mathrm{p}<0.05)$

$*=$ significant at $10 \%$ level $(p<0.10)$ 


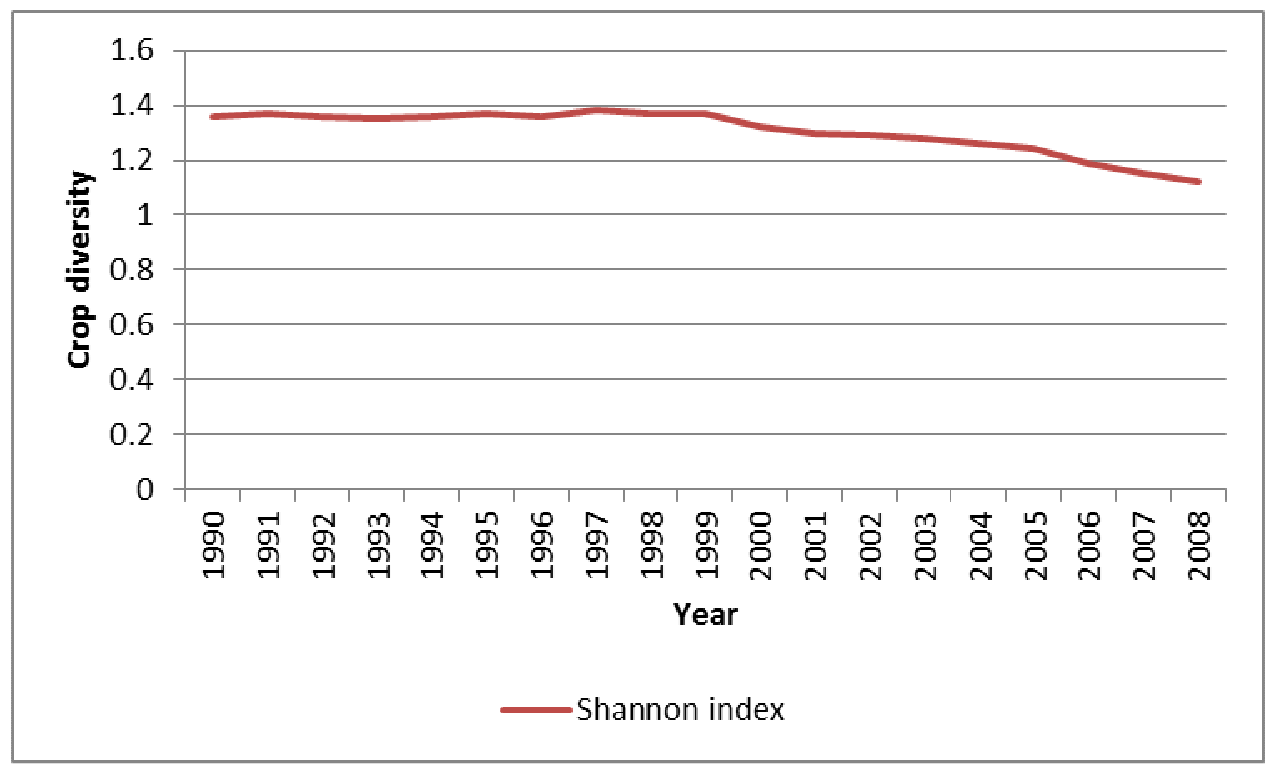

Figure 1. Shannon index of overall agricultural land use or crop diversity in Bangladesh (1990- 2008). 